\title{
Effect of different phytases on the performance, nutrient retention and tibia composition in broiler chickens
}

\author{
Anna Ptak1, Damian Józefiak², Bartosz Kierończyk², Mateusz Rawski², Krzysztof Żyła ${ }^{3}$ \\ and Sylwester Świątkiewicz ${ }^{4}$
}

1PIAST GROUP Research and Development Center, Ostrów Wielkopolski, Poland, ${ }^{2}$ Department of Animal Nutrition and Feed Management, University of Life Sciences, Poznań, Poland, ${ }^{3}$ Department of Food Biotechnology, University of Agriculture, Kraków, Poland, ${ }^{4}$ Department of Animal Nutrition and Feed Science, National Research Institute of Animal Production, Balice, Poland

\begin{abstract}
The effect of different phytases on the performance response, nutrient utilization and tibia characteristics of chickens was investigated. The five pelleted diets were the following: positive control (PC) with added monocalcium phosphate; negative control (NC) formulated with equivalency values of phytase for $\mathrm{Ca}$ and digestible $\mathrm{P}$; and three further diets where different phytases were individually added to the NC diet at $500 \mathrm{FTU} / \mathrm{kg}$. The phytases were derived either from Aspergillus (phytase I), or E. coli (phytases II and III). Compared to PC, the performance parameters, as well as apparent metabolizable energy (AMEn), mineral retention, bone breaking force and tibia mineral content were suppressed by the reduction of dietary Ca and digestible P. All phytases enhanced the overall body weight gains and feed conversion ratio in comparison with NC, but none outperformed PC. Only phytase II improved AMEn compared to NC and PC group. However only phytase I outperformed NC group in terms of mineral retention and $\mathrm{P}$ retention was higher than phytase II and III. No significant differences were observed in fat digestibility and $\mathrm{N}$ retention. Bone strength among phytases did not differ and all improved this parameter compared to the NC diet. However, even though all phytases enhanced tibia minerals content, the improvement was less pronounced with phytase III. Moreover, the differences in all analysed tibia minerals between phytase III and II were significant suggesting that even among 6-phytases derived from and expressed in the same organism, different efficacy or mode of action can occur.
\end{abstract}

Archiv Tierzucht 56 (2013) 104, 1028-1038

doi: 10.7482/0003-9438-56-104

Corresponding author:

Damian Józefiak; email: damjo@up.poznan.pl

Department of Animal Nutrition and Feed Management, University of Life Sciences, 60-637 Poznań, Poland

(c) 2013 by the authors; licensee Leibniz Institute for Farm Animal Biology (FBN), Dummerstorf, Germany. This is an Open Access article distributed under the terms and conditions of the Creative Commons Attribution 3.0 License (http://creativecommons.org/licenses/by/3.0/).
Received: 9 May 2013

Accepted: 19 November 2013

Online: 20 November 2013 
Keywords: broiler chickens; phytase; tibia; trace minerals

Abbreviations: AMEn: apparent metabolizable energy, BWG: body weight gain, FCR: feed conversion ratio, $\mathrm{NC}$ : negative control, PC: positive control

\section{Introduction}

Exogenous phytase preparations are probably one of the most commonly used feed additives in the feed industry and many phytase products are commercially available. Moreover, each year novel generations of the enzyme come onto the market but there is a wide variation in the recommended dosages of enzyme necessary for similar P release from feeds (Jones et al. 2010). Thus, potential users can be confused about the efficacy as well as about a proper application of a particular enzyme. Furthermore, it is well documented that benefits of phytase action are not restricted only to $\mathrm{Ca}$ and $\mathrm{P}$ release, but also include a better absorption of trace minerals. Pintar et al. (2005) demonstrated that phytase improved Fe and Mg levels in broiler tibias but had no effect on $\mathrm{Ca}, \mathrm{P}$ and $\mathrm{Zn}$ contents. In contrast, Shelton \& Southern (2006) demonstrated that the concentration of $\mathrm{Zn}$ in tibia was increased while $\mathrm{Fe}$ and Mn levels were not affected by a dietary phytase. In other studies, Yi et al. (1996) and Świątkiewicz et al. (2001) observed that phytase improved Zn utilization in broilers. Viveros et al. (2002) also observed that phytase supplementation increased $(P<0.0001) \mathrm{Ca}, \mathrm{P}, \mathrm{Mg}$ and $\mathrm{Zn}$ retention in broilers at three and six weeks of age. These inconsistent effects on the deposition of trace minerals in bones were probably linked to a different diet composition and diverse concentrations of phytates in feeds. However, the type of the phytase could have also played an important role. The usage of the phytase is also connected to better energy utilization of birds. In broiler chickens, metabolizable energy level results from a sum of many well available nutrients as well as from phytate presence which can impair digestibility of fat, protein or starch. Thus, the overall phytase effect on the apparent metabolizable energy (AMEn) gain, based on several studies, is estimated to be approximately $2.8 \%$. However, there are very few information available on how different supplementary phytases can affect AMEn levels in the same diet.

The objectives of this experiment were, therefore, to determine the effects of three different phytases on growth performance, AMEn values, nutrients digestibility, bonebreaking strength and tibia mineral content in broilers fed to market weight under commercial conditions.

\section{Material and methods}

\section{Birds and housing}

The experiment was carried out in floor pens $(1 \times 1 \mathrm{~m})$ arranged by blocks in the centre of a commercial chicken house. In order to simulate commercial production conditions, the experimental pens were surrounded by a commercial broiler flock comprising birds of the same origin and the same age as those used in the experiments. Five hundred 1-d old Ross 308 broiler male chickens, obtained from commercial hatchery and with an average initial 
weight of $41 \mathrm{~g}$, were selected and allotted randomly to the five experimental groups, using 10 replicate pens per treatment and 10 birds per pen. The birds were given $23 \mathrm{~h}$ of light and $1 \mathrm{~h}$ of dark during the first week and then $19 \mathrm{~h}$ of light and $5 \mathrm{~h}$ of dark from $\mathrm{d} 7$ to 21 . From 22 to $42 \mathrm{~d}$ of age, there was $23 \mathrm{~h}$ of light and $1 \mathrm{~h}$ of dark. The experiment complied with the guidelines of the Local Ethics Commission with respect to animal experimentation and care of animals under study.

\section{Diets and feeding program}

The compositions and nutritive values of the diets are shown in Table 1. The experimental diets were prepared from the same raw materials, which were stored before feed processing. All diets, with exception of finisher were produced with one batch. The finisher feeds were produced with two batches, with and without inert marker (TiO2). From day 21-35 and 40-42 birds were fed diets with $\mathrm{TiO} 2$ and from 35-40 d without. The negative control diets were formulated to meet or exceed NRC (1994) requirements for all nutrients except P and Ca. The positive control diet was formulated to meet or exceed the NRC (1994) requirement for all nutrients. The dietary treatments consisted of the control diet, negative control and the $P$ and $C$ a deficient diets supplemented with different phytase products at $500 \mathrm{FTU} / \mathrm{kg}$. All diets were supplemented with the ionophore coccidiostat salinomycin $(60 \mathrm{mg} / \mathrm{kg})$ from d 0 to 42 (Sacox, Huvepharma NV, Belgium). Diets were pelleted at $78{ }^{\circ} \mathrm{C}$ and were fed ad libitum throughout the starter (1-6d), grower (7-20d), and finisher (21-42d) phases of the experiment. Both, positive and negative control diets were prepared without addition of any phytase. The three further diets were the NC diets supplemented with $500 \mathrm{FTU} / \mathrm{kg}$ of either Aspergillus ficuum 3-phytase, EC 3.2.1.8 expressed in Aspergillus niger CBS 114.94 - Natuphos 5000 (phytase I), or Escherichia coli 6-phytase, EC 3.2.1.26, overproduced in Pichia pastoris DSM 15927 - Quantum 2500 (phytase II), or Escherichia coli 6-phytase, expressed in Pichia pastoris DSM 23036 - Hostazym P 5000 (phytase III).

\section{Measurements}

The chickens' body weight and feed intake were recorded at seven, 21 and $42 \mathrm{~d}$ of age. The body weight gain (BWG) and feed conversion ratio (FCR) were calculated for first (1-6 d), second (7-20), third (21-42 d) and the entire feeding period (1-42 d of age). Mortality and weights of dead birds were recorded twice daily.

For the evaluation of the AMEn nitrogen retention and total tract fat digestibility, $100 \mathrm{~g}$ of the excreta from each pen were collected at $40 \mathrm{~d}(\mathrm{n}=10)$. To avoid excreta contamination, $1 \mathrm{~h}$ before collection in each pen plastic cover was placed directly on the litter. The excreta samples were immediately frozen, freeze-dried and ground before further analyses. Five days (35-40 d) before sample collection birds were fed diets in which $0.3 \%$ of the wheat was replaced by titanium oxide as an internal marker for the calculation of nutrient digestibility.

At the termination of the experiment $(42 \mathrm{~d}$ ) from each experimental group, 10 randomly picked chickens (one bird/pen) were killed by cervical dislocation. The right tibias from 10 birds per each treatment (one bird/pen) were removed and frozen $\left(-20^{\circ} \mathrm{C}\right)$ until analysis. Measurement of the bones' breaking force was taken by means as described by Świątkiewicz et al. (2011). 
Table 1

Composition and nutrient content of the experimental diets

\begin{tabular}{|c|c|c|c|c|c|c|}
\hline \multirow[t]{2}{*}{ Item } & \multicolumn{2}{|c|}{$1-6 d$} & \multicolumn{2}{|c|}{$7-20 d$} & \multicolumn{2}{|c|}{$21-42 d$} \\
\hline & $\begin{array}{l}\text { Positive } \\
\text { control }\end{array}$ & $\begin{array}{l}\text { Negative } \\
\text { control }\end{array}$ & $\begin{array}{l}\text { Positive } \\
\text { control }\end{array}$ & $\begin{array}{l}\text { Negative } \\
\text { control }\end{array}$ & $\begin{array}{l}\text { Positive } \\
\text { control }\end{array}$ & $\begin{array}{l}\text { Negative } \\
\text { control }\end{array}$ \\
\hline \multicolumn{7}{|l|}{ Ingredients, \% } \\
\hline Wheat & 59.63 & 63.49 & 63.92 & 67.76 & 65.80 & 68.99 \\
\hline Rapeseed expeller & 5.00 & 5.00 & 10.00 & 10.00 & 10.00 & 10.00 \\
\hline Soybean meal & 27.43 & 26.21 & 17.57 & 16.37 & 15.68 & 15.11 \\
\hline Soybean oil & 4.20 & 2.37 & 5.39 & 3.56 & 5.69 & 3.91 \\
\hline Vitamin-mineral premix1 & 0.30 & 0.30 & 0.30 & 0.30 & 0.30 & 0.30 \\
\hline Monocalcium phosphate & 1.35 & 0.74 & 0.95 & 0.34 & 0.71 & 0.08 \\
\hline Limestone & 1.13 & 0.93 & 0.91 & 0.70 & 0.89 & 0.69 \\
\hline $\mathrm{NaCl}$ & 0.33 & 0.33 & 0.33 & 0.30 & 0.28 & 0.28 \\
\hline $\mathrm{Na} 2 \mathrm{CO} 3$ & 0.05 & 0.05 & 0.03 & 0.05 & 0.05 & 0.05 \\
\hline L-Lizyna $\mathrm{HCl}$ & 0.28 & 0.29 & 0.33 & 0.34 & 0.33 & 0.32 \\
\hline Methionine hydroxy analogu & 0.28 & 0.28 & 0.25 & 0.24 & 0.24 & 0.24 \\
\hline L-threonine & 0.04 & 0.04 & 0.05 & 0.06 & 0.06 & 0.05 \\
\hline \multicolumn{7}{|l|}{ Nutrient content, calculated } \\
\hline Crude protein, \% & 22.2 & 22.2 & 20.00 & 20.00 & 19.5 & 19.5 \\
\hline Dig. Lys, \% & 1.16 & 1.16 & 1.04 & 1.04 & 1.00 & 1.00 \\
\hline Dig. Met, \% & 0.53 & 0.53 & 0.48 & 0.48 & 0.47 & 0.47 \\
\hline Phosphorus-total, $\%$ & 0.72 & 0.59 & 0.64 & 0.50 & 0.57 & 0.44 \\
\hline P-digestible, $\mathrm{g} / \mathrm{kg}$ & 4.20 & 3.04 & 3.40 & 2.24 & 2.90 & 1.74 \\
\hline \multicolumn{7}{|l|}{ P-digestible - } \\
\hline \multicolumn{2}{|c|}{ phytase equivalency values, $\mathrm{g} / \mathrm{kg} 0$} & 1.16 & 0 & 1.16 & 0 & 1.16 \\
\hline Calcium-total, \% & 0.85 & 0.67 & 0.70 & 0.52 & 0.65 & 0.47 \\
\hline \multicolumn{7}{|l|}{ Calcium-total - } \\
\hline phytase equivalency values, 9 & 0 & 0.18 & 0 & 0.18 & 0 & 0.18 \\
\hline AMEn, $\mathrm{kcal} / \mathrm{kg}$ & 2980 & 2980 & 3110 & 3110 & 3150 & 3150 \\
\hline \multicolumn{7}{|l|}{$\begin{array}{l}\text { Analysed } \\
\text { phytase activity, FTU/ } \mathrm{kg}^{2,3}\end{array}$} \\
\hline no phytase addition & 76 & LQ & LQ & LQ & LQ & 106 \\
\hline phytase I (3-phytase) & - & 863 & - & 800 & - & 970 \\
\hline phytase II (6-phytase) & - & 443 & - & 529 & - & 620 \\
\hline phytase III (6-phytase) & - & 638 & - & 582 & - & 794 \\
\hline
\end{tabular}

'The premix provided per kg of diet: vitamin $\mathrm{A}, 11000 \mathrm{IU}$; vitamin $\mathrm{D}_{3^{\prime}} 2500 \mathrm{IU}$; vitamin $\mathrm{E}, 50 \mathrm{mg}$; vitamin $\mathrm{K} 3,2.50 \mathrm{mg}$; vitamin B1, 2.0 mg; vitamin B2, 7.0 mg; vitamin B5, $12.5 \mathrm{mg}$; vitamin B6, 4.0 mg; vitamin B12, $0.02 \mathrm{mg} ;$ niacin, $40 \mathrm{mg}$; folic acid, $1.0 \mathrm{mg}$; biotin $0.2 \mathrm{mg}$; choline chloride $300 \mathrm{mg} ; \mathrm{Mn}, 70 \mathrm{mg} ; \mathrm{Zn}, 55 \mathrm{mg} ; \mathrm{Fe}, 45 \mathrm{mg} ; \mathrm{Cu}, 20 \mathrm{mg} ; \mathrm{I}, 0.60 \mathrm{mg}$; and $\mathrm{Se}, 0.35 \mathrm{mg}$; Co, $0.25 \mathrm{mg}$. ${ }^{2} \mathrm{One}$ FTU the amount of phytase that catalyses the release of one micromole of inorganic phosphorus per minute from 5.1 millimoles of sodium phytate in $\mathrm{pH} 5.5$ buffer at $37^{\circ} \mathrm{C} .{ }^{3} \mathrm{Addition}$ of each phytase enzyme to the basal negative control diet was made at an activity level of $500 \mathrm{FTU} / \mathrm{kg}$ feed. LQ: limit of quantification

\section{Chemical analyses}

Feed samples were analysed in duplicate for crude protein, crude fat, crude fibre total $\mathrm{P}$ and phytase activity using AOAC (2005) methods 976.05, 920.39, 2002.04, 965.17 and 2000.12, respectively. The enzyme activities were measured in all diets and all periods. For finisher (21-42 d) feeds the phytase activities in table 1 are mean values of two batches (with and without TiO2) of this diet. For all chemical analyses, samples were ground to pass through a $0.5 \mathrm{~mm}$ sieve. The concentration of titanium dioxide was determined according to the method described by Short et al. (1996) and the samples were prepared according to the 
procedure reported by Myers et al. (2004). Gross energy, nitrogen and fat content were determined as described in details by Józefiak et al. (2010). Calcium, P, Na, K, Mg, Fe and Zn concentrations were measured in the right tibia and $\mathrm{Ca}$ and $\mathrm{P}$ in excreta. The tibias were cleaned from adherent tissue and ashed $\left(550^{\circ} \mathrm{C}\right.$ for $\left.14 \mathrm{~h}\right)$. Ash weight was calculated relative to tibial dry weight. The resultant ash was solubilized on a sand heater (300VC $15 \mathrm{~min}$ ) in $10 \mathrm{ml} 6 \mathrm{~N} \mathrm{HCl}$ and $30 \mathrm{ml}$ demineralized water. The solution was transferred after filtration (ashless filters) into a $100 \mathrm{ml}$ volumetric flask. The $\mathrm{Ca}, \mathrm{P}, \mathrm{Na}, \mathrm{K}, \mathrm{Mg}$, Fe and $\mathrm{Zn}$ concentrations were measured by Atomic Absorption Spectrophotometry (VARIAN Techtron AA 475, Pty. Ltd. Springvale, Australia) as described by Revy et al. (2004).

\section{Digestibility calculations}

The apparent digestibility coefficients and AMEn contents of the experimental diets were analysed as described in detail by Józefiak et al. (2010).

\section{Statistical analysis}

Statistical analysis was conducted using the GLM procedure of SAS software (SAS 1990, SAS Institute Inc., Cary, NC, USA). All the data were analysed using one-way ANOVA. Means were separated using a Duncan's multiple range test. All statements of significance are based on $P<0.05$.

\section{Results}

The results of the experiment are shown in tables 2-4. In the first period of the trial (1-6 d) the reduction of $P$ and $C$ a levels as well as the supplementation of different kinds of phytase products had no effect on the performance (Table 2). However, during the grower phase (7-20 d) the NC diets with a low P and Ca concentration negatively affected BWG and FCR compared to PC diet $(P<0.05)$. Moreover, only phytase II significantly enhanced body weight gains from 7 to $20 \mathrm{~d}$ compared to the NC group. No differences among groups in terms of feed intake were noted in grower phase. Also in this period all tested phytase products improved FCR in comparison with the NC treatment, however, only the group supplemented with phytase III produced FCR values that did not differ from the positive control. In the last stage of broiler growth (21-42 d), the lowest BWG was found in the NC treatment, and it did not differ only from the group supplemented with phytase I. Furthermore, the reduction of $P$ and Ca levels resulted in a significantly poorer FCR than that recorded in the rest of experimental groups. However, none of supplemental phytase products improved FCR compared to the PC group. Additionally, the highest feed intake was noted in birds fed phytase II followed by those that received phytase III and then those fed the NC diet. This was also evident when the parameter was calculated for the entire experimental period (1-42 d).

No significant differences among experimental treatments were observed in fat digestibility and in $\mathrm{N}$ retention. However, feed supplementation with phytase II increased AMEn. Moreover, the phytase addition produced the highest AMEn value among all experimental groups, including the PC. The reduction of $P$ and $C$ a levels had a negative effect on the calcium retention in broilers and only phytase I supplementation removed the effect. 
Also, compared to the NC treatment, the phosphorus retention was increased only in broilers fed the diet supplemented with phytase I.

The lowest bone breaking force was reported in the NC group $(P<0.05)$. Furthermore, the NC group had also significantly lower levels of mineral content in tibia bones than found in other treatments. The only exception was the level of Fe, for which the differences between the NC treatment and the treatment with supplemental phytase III were not statistically significant. In terms of K, Mg and Fe levels in tibiae, the addition of phytase III did not show any improvement compared to the PC diet. Moreover, only broilers fed the diets with added phytase I had tibia $\mathrm{Na}$ and $\mathrm{Zn}$ contents that were significantly higher than in birds fed the PC diet.

Table 2

The effect of different sources of phytase supplementation on the growth performance of broilers

\begin{tabular}{|c|c|c|c|c|c|c|c|}
\hline Treatment $^{1}$ & $\begin{array}{l}\text { Positive } \\
\text { Control }\end{array}$ & $\begin{array}{c}\text { Negative } \\
\text { Control }\end{array}$ & $\begin{array}{c}\mathrm{NC}+ \\
\text { phytase I }\end{array}$ & $\begin{array}{c}\mathrm{NC}+ \\
\text { phytase II }\end{array}$ & $\begin{array}{c}\mathrm{NC}+ \\
\text { phytase III }\end{array}$ & $\begin{array}{c}\text { Pooled } \\
\text { SEM }\end{array}$ & $\begin{array}{c}\text { Model } \\
\text { P }\end{array}$ \\
\hline \multicolumn{8}{|c|}{ Body weight gain², g } \\
\hline $1-6 d$ & 145 & 139 & 145 & 145 & 140 & 0.940 & 0.178 \\
\hline $7-20 d$ & $821^{\mathrm{ab}}$ & $775^{c}$ & $790^{\mathrm{bc}}$ & $833^{\mathrm{a}}$ & $808^{a b c}$ & 5.261 & 0.006 \\
\hline $21-42 d$ & $2134^{\mathrm{ab}}$ & $2049^{c}$ & $2095^{c b}$ & $2183^{a}$ & $2146^{\mathrm{ab}}$ & 10.953 & 0.004 \\
\hline $1-42 d$ & $3101^{\mathrm{ab}}$ & $2963^{c}$ & $3029^{b c}$ & $3161^{a}$ & $3094^{\mathrm{ab}}$ & 13.967 & 0.0002 \\
\hline \multicolumn{8}{|c|}{ Feed intake ${ }^{2}, \mathrm{~g}$} \\
\hline $1-6 d$ & 145 & 145 & 148 & 149 & 145 & 0.634 & 0.246 \\
\hline $7-20 d$ & 1124 & 1142 & 1125 & 1168 & 1128 & 5671 & 0.125 \\
\hline $21-42 d$ & $3847^{c}$ & $3946^{\mathrm{abc}}$ & $3882^{\mathrm{bc}}$ & $4035^{a}$ & $3977^{\mathrm{ab}}$ & 17.573 & 0.013 \\
\hline $1-42 d$ & $5116^{b}$ & $5233^{a b}$ & $5155^{b}$ & $5351^{\mathrm{a}}$ & $5249^{a b}$ & 20.868 & 0.009 \\
\hline \multicolumn{8}{|c|}{ Feed conversion ratio ${ }^{2}, \mathrm{~g} / \mathrm{g}$} \\
\hline $1-6 d$ & 1.00 & 1.04 & 1.02 & 1.03 & 1.03 & 0.004 & 0.055 \\
\hline $7-20 d$ & $1.37^{d}$ & $1.47^{\mathrm{a}}$ & $1.43^{b}$ & $1.40^{\mathrm{bc}}$ & $1.40^{\mathrm{cd}}$ & 0.006 & $<.0001$ \\
\hline $21-42 d$ & $1.80^{c}$ & $1.93^{\mathrm{a}}$ & $1.86^{b}$ & $1.85^{\mathrm{b}}$ & $1.85^{\mathrm{b}}$ & 0.007 & $<.0001$ \\
\hline $1-42 d$ & $1.65^{c}$ & $1.77^{\mathrm{a}}$ & $1.70^{b}$ & $1.69^{b}$ & $1.70^{\mathrm{b}}$ & 0.006 & $<.0001$ \\
\hline
\end{tabular}

${ }_{a, b}$ Means in the rows with different letters are significantly different at $P<0.05 .$, SEM: standard error of the mean, Model P: model probability, 'Positive control-diet optimized with monocalcium phosphate; negative control-diet formulated with phytase matrix which reduced Ca level by $0.18 \%$ and digestible P by $0.12 \%$; phytase I - NC diet supplemented with of Aspergillus ficuum 3-phytase produced by Aspergillus niger CBS 114.94 (500 FTU/kg feed); phytase II - NC diet supplemented with of Escherichia coli 6-phytase produced by Pichia pastoris DSM 15927 (500 FTU/kg feed); phytase III - NC diet supplemented with of Escherichia coli 6-phytase produced by Pichia pastoris DSM 23036 (500 FTU/kg feed). ${ }^{2}$ Values are means, $\mathrm{n}=10$.

Table 3

The digestibility results at $40 \mathrm{~d}$ based on titanium oxide retention in broiler chickens fed diets with different sources of the exogenous phytase

\begin{tabular}{lccccccc}
\hline Treatment $^{1}$ & $\begin{array}{c}\text { Positive } \\
\text { Control }\end{array}$ & $\begin{array}{c}\text { Negative } \\
\text { Control }\end{array}$ & $\begin{array}{c}\text { NC }+ \\
\text { phytase I }\end{array}$ & $\begin{array}{c}\text { NC }+ \\
\text { phytase II }\end{array}$ & $\begin{array}{c}\text { NC }+ \\
\text { phytase III }\end{array}$ & $\begin{array}{c}\text { Pooled } \\
\text { SEM }\end{array}$ & $\begin{array}{c}\text { Model } \\
\text { P }\end{array}$ \\
\hline AMEn $^{2}, \mathrm{kcal}^{\prime} \mathrm{kg}$ & $2988^{\mathrm{bc}}$ & $2958^{\mathrm{c}}$ & $3021^{\mathrm{bc}}$ & $3138^{\mathrm{a}}$ & $3031^{\mathrm{bc}}$ & 19.758 & 0.046 \\
Fat digestibilty $^{2}, \%$ & 84.86 & 84.36 & 86.59 & 86.25 & 87.09 & 0.461 & 0.376 \\
N retention $^{2} \%$ & 57.78 & 54.52 & 56.81 & 58.38 & 57.65 & 0.505 & 0.122 \\
Ca retention $^{2} \%$ & $74.36^{\mathrm{a}}$ & $68.27^{\mathrm{b}}$ & $74.31^{\mathrm{a}}$ & $70.97^{\mathrm{ab}}$ & $68.95^{\mathrm{b}}$ & 0.749 & 0.020 \\
P retention $^{2}, \%$ & $65.59^{\mathrm{ab}}$ & $60.73^{\mathrm{b}}$ & $68.45^{\mathrm{a}}$ & $60.34^{\mathrm{b}}$ & $62.21^{\mathrm{b}}$ & 0.920 & 0.020 \\
\hline
\end{tabular}

a,b Means in the rows with different letters are significantly different at $P<0.05$. SEM: standard error of the mean, Model $P$ : Model probability, 1 Positive control-diet optimized with monocalcium phosphate; negative control-diet formulated with phytase matrix which reduced Ca level by $0.18 \%$ and digestible $\mathrm{P}$ by $0.12 \%$; phytase I - NC diet supplemented with of Aspergillus ficuum 3-phytase produced by Aspergillus niger CBS 114.94 (500 FTU/kg feed); phytase II - NC diet supplemented with of Escherichia coli 6-phytase produced by Pichia pastoris DSM 15927 (500 FTU/kg feed); phytase III - NC diet supplemented with of Escherichia coli 6-phytase produced by Pichia pastoris DSM 23036 (500 FTU/kg feed), ${ }^{2}$ Values are means, $\mathrm{n}=10$. 
Table 4

Tibia minerals and tibial bone breaking force in broiler chickens fed diets with different sources of the exogenous phytase (41 d)

\begin{tabular}{lccccccc}
\hline Treatment $^{1}$ & $\begin{array}{c}\text { Positive } \\
\text { Control }\end{array}$ & $\begin{array}{c}\text { Negative } \\
\text { Control }\end{array}$ & $\begin{array}{c}\mathrm{NC}+ \\
\text { phytase I }\end{array}$ & $\begin{array}{c}\mathrm{NC}+ \\
\text { phytase II }\end{array}$ & $\begin{array}{c}\mathrm{NC}+ \\
\text { phytase III }\end{array}$ & $\begin{array}{c}\text { Pooled } \\
\text { SEM }\end{array}$ & $\begin{array}{c}\text { Model } \\
\mathrm{P}\end{array}$ \\
\hline Bone breaking force $^{2}, \mathrm{~N}$ & $392^{\mathrm{a}}$ & $329^{\mathrm{b}}$ & $360^{\mathrm{a}}$ & $372^{\mathrm{a}}$ & $378^{\mathrm{a}}$ & 4.833 & 0.001 \\
$\mathrm{Ca}^{2}, \%$ & $37.25^{\mathrm{ab}}$ & $30.76^{\mathrm{c}}$ & $37.57^{\mathrm{a}}$ & $38.17^{\mathrm{a}}$ & $35.94^{\mathrm{b}}$ & 0.387 & $<.0001$ \\
$\mathrm{P}^{2}, \%$ & $20.22^{\mathrm{ab}}$ & $16.45^{\mathrm{c}}$ & $20.42^{\mathrm{ab}}$ & $20.46^{\mathrm{a}}$ & $19.60^{\mathrm{b}}$ & 0.215 & $<.0001$ \\
$\mathrm{Na}^{2}, \%$ & $1.259^{\mathrm{bc}}$ & $1.093^{\mathrm{d}}$ & $1.325^{\mathrm{a}}$ & $1.275^{\mathrm{ab}}$ & $1.205^{\mathrm{c}}$ & 0.012 & $<.0001$ \\
$\mathrm{~K}^{2}, \%$ & $0.764^{\mathrm{a}}$ & $0.586^{\mathrm{c}}$ & $0.735^{\mathrm{a}}$ & $0.753^{\mathrm{a}}$ & $0.664^{\mathrm{b}}$ & 0.011 & $<.0001$ \\
$\mathrm{Mg}^{2}, \%$ & $0.863^{\mathrm{a}}$ & $0.657^{\mathrm{c}}$ & $0.883^{\mathrm{a}}$ & $0.863^{\mathrm{a}}$ & $0.769^{\mathrm{b}}$ & 0.012 & $<.0001$ \\
$\mathrm{Fe}^{2}, \mathrm{mg}$ & $375^{\mathrm{a}}$ & $286^{\mathrm{b}}$ & $394^{\mathrm{a}}$ & $417^{\mathrm{a}}$ & $261^{\mathrm{b}}$ & 13.004 & 0.0002 \\
$\mathrm{Zn}^{2}, \mathrm{mg}$ & $484^{\mathrm{bc}}$ & $287^{\mathrm{d}}$ & $535^{\mathrm{a}}$ & $508^{\mathrm{ab}}$ & $450^{\mathrm{c}}$ & 12.110 & $<.0001$ \\
\hline
\end{tabular}

${ }^{a, b}$ means in the rows with different letters are significantly different at $P<0.05, \mathrm{SEM}$ : standard error of the mean, Model $P$ : Model probability, 1Positive control - diet optimized with monocalcium phosphate; negative control - diet formulated with phytase matrix which reduced Ca level by $0.18 \%$ and digestible P by $0.12 \%$; phytase I - NC diet supplemented with of Aspergillus ficuum 3-phytase produced by Aspergillus niger CBS 114.94 (500 FTU/kg feed); phytase II - NC diet supplemented with of Escherichia coli 6-phytase produced by Pichia pastoris DSM 15927 (500 FTU/kg feed); phytase III - NC diet supplemented with of Escherichia coli 6-phytase produced by Pichia pastoris DSM 23036 (500 FTU/kg feed), ${ }^{2}$ Values are means, $\mathrm{n}=10$.

\section{Discussion}

The commercial preparations of phytases used in poultry nutrition differ in origin, mode of action and form. Phytases are phosphatases capable of hydrolysing one or more phosphate groups. Depending on the position of the phosphate group on the myo-inositol ring which they hydrolyse first, they belongs to one of two sub-classes: 3-phytase and 6-phytase. The 3-phytase initiates phytate hydrolysis by removing phosphate residue from position three of the myo-inositol ring, and 6-phytase from position six or four of the phytic acid molecule (Żyła et al. 2004). Phytases differ also in terms of $\mathrm{pH}$-activity profile, thermo stability and in resistance to digestive enzymatic degradation in the animal intestine (Lei \& Stahl 2001, Onyango et al. 2004, Bedford \& Cowieson 2009). As a result, different commercial phytase products may generate different efficacies under practical conditions.

There is a great deal of evidence showing that the addition of exogenous phytases to the diets of poultry improves weight gains, mineral retention, AMEn, and amino acid digestibility (Ravindran et al. 1999, Newkirk \& Classen 2001, Murai et al. 2002, Rutherfurd et al. 2002, Augspurger et al. 2003, Cowieson \& Adeola 2005, Józefiak et al. 2010, Żyła et al. 2013). The results obtained in the present study also support the findings that phytase supplementation beneficially affects production parameters of broilers. The growth response of birds fed a phytase supplemented diet did not differ from that of the positive control treatment in any of the experimental periods. This would indicate that the adequate amounts of $\mathrm{P}$ were released from the phytate molecule to support the growth. However, it seems that the effect of addition of 6-phytase products, and particularly the phytase II on body weight gains, was more pronounced than that obtained by 3-phytase (phytase I) supplementation. This effect was not observed in relation to the FCR. Contrary to the expectation, the effect of reducing the $\mathrm{Ca}$ and $\mathrm{dP}$ concentration in the diet and supplementation of phytases on feed intake was small. The negative control diet was formulated to contain around 0.18 to $0.12 \%$ less $C a$ and $\mathrm{dP}$ than the positive control diet, and it was expected that this would result in a decrease 
in both BWG and feed intake. However, very low dietary Ca concentrations could influence the digestibility of phytate-P (and possibly nonphytate-P). Tamim et al. (2004) found out that phytate-P digestibility, in the absence of phytase, could be increased to almost $80 \%$ if dietary Ca concentration was reduced to around $0.2 \%$. In the present study, dietary $\mathrm{Ca}$ concentrations were reduced by $0.18 \%$, and possibly changed the negative effect of the removal of the inorganic $P$.

Phytase supplementation also improved retention of minerals and AMEn level but did not affect fat digestibility and nitrogen retention. The lowest AMEn was measured in birds fed the NC diet while the highest was found in those that received feeds supplemented with phytase II or with phytase III $(P<0.05)$. In a dose response trial, in which phytase was used at graded levels up to $12,000 \mathrm{FTU} / \mathrm{kg}^{-1}$, a gradual increase in the AMEn and $\mathrm{N}$ retention was demonstrated (Shirley \& Edwards 2003). In contrast to these findings, the addition of the enzyme at seven levels of activity in the range from 0 to $1000 \mathrm{FTU} \mathrm{kg}^{-1}$ to broiler diets containing 7.5 and $3.0 \mathrm{~g}$ total $\mathrm{P} \mathrm{kg}{ }^{-1}$ slightly enhanced the AMEn values which reached a plateau at $750 \mathrm{FTU} \mathrm{kg}^{-1}$ (Ravindran et al. 2001). In the present trial supplementation of the broiler diets with phytase II significantly increased the AMEn level compared to PC and NC treatments. However, this was not reflected in the feed utilization, nitrogen retention and fat digestibility. Data from other studies indicate that the percentage responses in AMEn following phytase supplementation are negatively correlated $(r=-0.562 ; P<0.02)$ to the energy density of the control diets (Selle \& Ravindran 2007). In the present study, the diets with added phytase II (6-phytase) returned higher values of AMEn $(P<0.05)$ than the diets supplemented with phytase I (3-phytase). These results are in partial agreement with the findings of Bedford \& Cowieson (2009), who stated that for equivalent $P$ release the 6-phytase would need to deplete a greater proportion of the phytate pool than 3-phytase. Therefore, compared to 3-phytases, the energy and amino acid matrices of a 6-phytase are usually larger per one unit of enzyme activity. However, results from the current study also demonstrate that even though both of the 6-phytase (II and III) are Escherichia coli-derived, both are overproduced in the same expression system of Pichia pastoris and both produced similar performances of the experimental birds, they give different responses in the AMEn values. This effect might have depended on the Pichia pastoris strain employed in both expression systems of the methylotrophic yeast which was different in phytase II than in phytase III. Furthermore, another discrepancy that evolved, when these three phytase products were compared, concerned mineral retention. In the current experiment, only birds fed phytase I supplemented diet outperformed $(P<0.05)$ those on the deficient diet (NC) in both $\mathrm{Ca}$ and $\mathrm{P}$ retention, although similar Ca retention was characteristic for birds fed phytase II. Experimental data from research in which the sub-classes of phytase (3-phytase vs. 6-phytase) have been compared are contradictory. Augspurger et al. (2003) and Augspurger \& Baker (2004) reported that at lower levels of phytase activity (i.e., 500 and 1,000 FTU/kg) E. coli-derived 6-phytase maintained a greater than a threefold advantage in P-releasing efficacy thanr fungal 3 and 6-phytases. In contrast, Tamim et al. (2004) demonstrated a higher ileal disappearance of phytate $P$ and apparent absorption of $P$ when 3-phytase was used compared with a 6-phytase. Also Żyła et al. (2004), in the in vitro model, provided evidence that 3-phytase released significantly more $P$ than 6-phytase. A possible explanation for these varied results could be the different phytase origin (fungal or bacterial) and dissimilar diet ingredients used in the studies. Nevertheless, in the current study P retention did not differ 
between control treatments. The lack of a negative impact, and even a superior $\mathrm{P}$ retention in birds fed the deficient diet (NC) compared with the positive control die,t was also reported by Viveros et al. (2002) and Onyango et al. (2004). These authors attributed the effect to a greater ability of birds to retain $\mathrm{P}$ from diets with lower rather than higher nonphytate $\mathrm{P}$ content.

The skeletal integrity in poultry is affected by numerous factors, including nutritional regime, genetic factors, sex, age, management conditions and production system (Kleczek et al. 2012, Yildiz et al. 2009). In the present study, all of the phytases studied improved the tibial bone breaking force to the level found in the positive control group $(P<0.05)$. Thus the minerals retention was not reflected in this parameter. Generally, this is in agreement with many other studies (Augspurger et al. 2003, Sands et al. 2003, Onyango et al. 2004, Payne et al. 2005) indicating therefore that irrespective of phytase sub-class or dosage, bone characteristics are positively affected by a dietary inclusion of the enzyme. However, some data do not show that phytase supplementation had a significant effect on bone mineralization in broilers (Perney et al. 1993, Żyła et al. 2000). In many studies, phytase supplementation affected macro and trace minerals content in tibia (Viveros et al. 2002, Pintar et al. 2005). Ravindran et al. (1995) demonstrated that bone mineralization criteria are more sensitive indicators of $P$ status in birds than growth criteria. In our study, irrespective of the analysed element, the lowest concentrations were found in tibiae of broilers fed the NC treatment. In case of the $\mathrm{Ca}$, $\mathrm{P}$ and $\mathrm{Na}$, all of phytases improved their depositions to levels found in the positive control. For $\mathrm{K}, \mathrm{Mg}$, Fe and Zn contents in the tibiae, the lowest values were characteristic for birds fed the diet supplemented with phytase III compared to those that consumed phytase I or II. Pintar et al. (2005) observed a positive effect of phytase on Fe and Mg content in tibia, but, in contrast to the present work, no effect on Zn concentration. In yet another study (Shelton \& Southern 2006), the removal of a trace mineral premix from a diet or phytase supplementation had no effect on Fe concentration in tibia. In the present study, similarly to many others (Mohanna \& Nys 1999, Zanini \& Sazzad 1999, Świątkiewicz et al. 2001, Viveros et al. 2002, Shelton \& Southern 2006) phytase has been shown to increase the availability of Zn. In the previous study of Shelton \& Southern (2006) bone strength was decreased in chicks fed diets with no supplemental $\mathrm{Zn}$, while the removal of $\mathrm{Mn}$ and $\mathrm{Cu}$ from a diet did not affect bone strength. It could be suggested that the higher concentrations of $\mathrm{Zn}$ and other trace minerals in tibia, observed in the current trial in chickens fed diets supplemented with phytase I and II, was reflected in the strength of bones. However, this trend was less pronounced with phytase III.

In the present study the activity in phytase products were not measured, what may be one of the contributing factor of big differences between formulated and determined dietary phytase activities. However, large variation in assay results, and poor reproducibility often occurs when AOAC method is used to determine phytase activity especially when different phytase products are taken into consideration (Isaksen \& Dalsgaard 2007, Gizzi et al. 2008, Kim \& Lei 2005).

Phytase sub-class, the source as well as the microbial expression system may alter the biochemical and biophysical properties of the enzyme, which in turn affect the in vivo bio efficacy of phytases. Results from the present study also suggest that the strain of an organism used for overexpression of the enzyme may play a role in the efficacy of phytase what is in agreement with Onyango et al. (2004). All these factors, in addition to the catalytic activity alter the deposition of trace minerals in tibiae of broiler chickens. 


\section{References}

AOAC (2005) Official methods of analysis. 18th ed., Association of Official Analytical Chemists, Washington, D.C., USA

Augspurger NR, Baker DH (2004) High dietary phytase levels maximize phytate-phosphorus utilization but do not affect protein utilization in chicks fed phosphorus- or amino acid-deficient diets. J Anim Sci 82, 1100-1107

Augspurger NR, Webel DM, Lei XG, Baker DH (2003) Efficacy of an E. coli phytase expressed in yeast for releasing phytate-bound phosphorus in young chicks and pigs. J Anim Sci 81, 474-483

Bedford MR, Cowieson AJ (2009) Phytase and Phytate Interactions. In: Proc 17th Eur Symp Poult Nutr, Edinburgh, Scotland, 7-13

Cowieson AJ, Adeola O (2005) Carbohydrases, protease, and phytase have an additive beneficial effect in nutritionally marginal diets for broiler chicks. Poult Sci 84, 1860-1867

Gizzi G, Thyregod P, von Holst C, Bertin G, Vogel K, Faurschou-Isaksen M, Betz R, Murphy R, Andersen BB (2008) Determination of Phytase Activity in Feed: Interlaboratory Study. J AOAC Int 91, 259-267

Isaksen MF, Dalsgaard S (2007) Factors affecting phytase activity: Implication for assay development. J Anim Sci 85 (Suppl.), 157

Jones CK, Tokach MD, Dritz SS, Ratliff BW, Horn NL, Goodband RD, DeRouchey JM, Sulabo RC, Nelssen JL (2010) Efficacy of different commercial phytase enzymes and development of an available phosphorus release curve for Escherichia coli-derived phytases in nursery pigs. J Anim Sci 88, 3631-3644

Józefiak D, Ptak A, Kaczmarek S, Maćkowiak P, Sassek M, Slominski BA (2010) Multi-carbohydrase and phytase supplementation improves growth performance and liver insulin receptor sensitivity in broiler chickens fed diets containing full-fat rapeseed. Poult Sci 89, 1939-1946

Kim TW, Lei XG (2005) An improved method for a rapid determination of phytase activity in animal feed. J Anim Sci 83, 1062-1067

Kleczek K, Majewska K, Makowski W, Michalik D (2012) The effect of diet supplementation with propolis and bee pollen on the physicochemical properties and strength of tibial bones in broiler chickens. Arch Tierz $55,97-103$

Lei XG, Stahl CH (2001) Biotechnological development of effective phytases for mineral nutrition and environmental protection. Appl Microbiol Biotechnol 57, 474-481

Mohanna C, Nys Y (1999) Changes in zinc and manganese availability in broiler chicks induced by vegetal and microbial phytases. Anim Feed Sci Technol 77, 241-253

Murai A, Kobayashi T, Okada T, Okumura J (2002) Improvement of growth and nutritive value in chicks with non-genetically modified phytase product from Aspergillus niger. Br Poult Sci 43, 687-695

Myers WD, Ludden PA, Nayigihugu V, Hess BW (2004) Technical Note: A procedure for the preparation and quantitative analysis of samples for titanium dioxide. J Anim Sci 82, 179-183

Newkirk RW, Classen HL (2001) The non-mineral nutritional impact of phytate in canola meal fed to broiler chicks. Anim Feed Sci Technol 91, 115-128

NRC (1994) Nutrient Requirements of Poultry, 9th rev. ed., National Research Council, Washington, D.C., USA

Onyango EM, Bedford MR, Adeola O (2004) The yeast production system in which Escherichia coli phytase is expressed may affect growth performance, bone ash, and nutrient use in broiler chicks. Poult Sci 83, 421-427

Payne RL, Lavergne TK, Southern LL (2005) A comparison of two sources of phytase in liquid and dry forms in broilers. Poult Sci 84, 265-272

Perney KM, Cantor AH, Straw ML, Herkelman KL (1993) The Effect of Dietary Phytase on Growth Performance and Phosphorus Utilization of Broiler Chicks. Poult Sci 72, 2106-2114

Pintar J, Homen B, Gazić K, Janječić Z, Sikirić M, Černy T (2005) Effects of supplemental phytase on nutrient excretion and retention in broilers fed different cereal based diets. Czech J Anim Sci 50, 40-46

Ravindran V, Cabahug S, Ravindran G, Bryden WL (1999) Influence of microbial phytase on apparent ileal amino acid digestibility of feedstuffs for broilers. Poult Sci 78, 699-706 
Ravindran V, Kornegay ET, Potter LM, Ogunabameru BO, Welten MK, Wilson JH, Potchanakorn M (1995) An Evaluation of Various Response Criteria in Assessing Biological Availability of Phosphorus for Broilers. Poult Sci 74, 1820-1830

Ravindran V, Selle PH, Ravindran G, Morel PCH, Kies AK, Bryden WL (2001) Microbial phytase improves performance, apparent metabolizable energy, and ileal amino acid digestibility of broilers fed a lysinedeficient diet. Poult Sci 80, 338-344

Revy PS, Jondreville C, Dourmad JY, Nys Y (2004) Effect of zinc supplementation as either an organic or an inorganic source and of microbial phytase on zinc and other minerals utilisation by weanling pigs. Anim Feed Sci Technol 116, 93-112

Rutherfurd SM, Chung TK, Moughan PJ (2002) The effect of microbial phytase on ileal phosphorus and amino acid digestibility in the broiler chicken. Br Poult Sci 43, 598-606

Sands JS, Stilborn R, Berg J, Salmon RE (2003) Comparative efficacy of two microbial phytases for improving performance in broilers fed low-P diets. Poult Sci 82 (Suppl 1), 118

SAS (1990) SAS/STAT User's Guide, Version 6. SAS Institute Inc., Cary, NC, USA

Selle PH, Ravindran V (2007) Microbial phytase in poultry nutrition. Anim Feed Sci Technol 135, 1-41

Shelton JL, Southern LL (2006) Effects of Phytase Addition with or Without a Trace Mineral Premix on Growth Performance, Bone Response Variables, and Tissue Mineral Concentrations in Commercial Broilers. J Appl Poult Res 15, 94-102

Shirley RB, Edwards Jr HM (2003) Graded levels of phytase past industry standards improves broiler performance. Poult Sci 82, 671-680

Short FJ, Gorton P, Wiseman J, Boorman KN (1996) Determination of titanium dioxide added as an inert marker in chicken digestibility studies. Anim Feed Sci Technol 59, 215-221

Świątkiewicz S, Koreleski J, Arczewska-Włosek A (2011) Effect of inulin and oligofructose on performance and bone characteristics of broiler chickens fed on diets with different concentrations of calcium and phosphorus. Br Poult Sci 52, 483-491

Świątkiewicz S, Koreleski J, Zhong DQ (2001) The bioavailability of zinc from inorganic and organic sources in broiler chickens as affected by addition of phytase. J Anim Feed Sci 10, 317-328

Tamim NM, Angel R, Christman M (2004) Influence of dietary calcium and phytase on phytate phosphorus hydrolysis in broiler chickens. Poult Sci 83, 1358-1367

Viveros A, Brenes A, Arija I, Centeno C (2002) Effects of microbial phytase supplementation on mineral utilization and serum enzyme activities in broiler chicks fed different levels of phosphorus. Poult Sci 81, 1172-1183

Yi Z, Kornegay ET, Denbow DM (1996) Supplemental Microbial Phytase Improves Zinc Utilization in Broilers. Poult Sci 75, 540-546

Yildiz H, Gunes N, Gezen SS, Ozcan R, Petek M, Yilmaz B, Arican I (2009) Effects of ascorbic acid and lighting schedule on tibiotarsus strength and bone characteristics in broilers. Arch Tierz 52, 432-444

Zanini SF, Sazzad MH (1999) Effects of microbial phytase on growth and mineral utilisation in broilers fed on maize soybean-based diets. Br Poult Sci 40, 348-352

Żyła K, Duliński R, Pierzchalska M, Grabacka M, Józefiak D, Świątkiewicz S (2013) Phytases and myo-inositol modulate performance, bone mineralization and alter lipid fractions in serum of broilers. J Anim Feed Sci $22,56-62$

Żyła K, Koreleski J, ŚwiątkiewiczS, Wikiera A, Kujawski M, Piironen J, Ledoux DR (2000) Effects of phosphorolytic and cell wall-degrading enzymes on the performance of growing broilers fed wheat-based diets containing different calcium levels. Poult Sci 79, 66-76

Żyła K, Mika M, Stodolak B, Wikiera A, Koreleski J, Świątkiewicz S (2004) Towards complete dephosphorylation and total conversion of phytases in poultry feeds. Poult Sci 83, 1175-1186 